\title{
Rumah Bernyanyi Sebagai Sarana Penyimpangan Sosial
}

\author{
Syamsir Alamsyah \\ Sulfasyah \\ Universitas Muhammadiyah Makassar \\ sulfahsyah@unsimuh.ac.id \\ Mas'ud Ibrahim \\ Universitas Muhammadiyah Makassar \\ masudibrahim@unsimuh.ac.id
}

\begin{abstract}
ABSTRAK
Penelitian ini bertujuan untuk mengetahui penyimpangan sosial rumah bernyanyi di kecamatan maniangpajo Kabupaten Wajo. Jenis penelitian ini adalah penelitian sosial budaya (PSB) dengan tipe deskriptif kualitatif, yaitu memberikan gambaran tentang perilaku menyimpang dan persepsi masyarakat dalam hal ini rumah bernyanyi di masyarakat Maniangpajo Kabupaten Wajo. Pengumpulan data dalam penelitian ini dilakukan dengan cara observasi, wawancara dan dokumentasi serta partisipatif. Untuk menentukan sampel sebagai sasaran dalam penelitian ini, peneliti melakukan teknik Purposive Sampling. Pengumpulan data dalam penelitian ini dilakukan melalui observasi, wawancara, dan dokumentasi. Data yang telah dikumpulkan dianalisis dengan analisis data kualitatif. Hasil penelitian ini menunjukkan bahwa penyebab adanya persepsi masyarakat tentang rumah bernyanyi ini adalah karena adanya dampak yang dirasakan oleh masyarakat sehingga mereka mengeluarkan tanggapannya baik itu tanggapan persepsi positif maupun tanggapan persepsi negatif. Adapun dampak yang ditimbulkan selain memiliki dampak negatif juga memiliki dampak positif adanya rumah bernyanyi, salah satu dampak negatifnya adalah pengunjung sering mengganggu ketenangan masyarakat sekitar dengan cara mabuk-mabukan, dan adapun dampak positifnya memberikan penghasilan kepada tukang parkir dan pekerja rumah bernyanyi tersebut dan bisa pula di jadikan tempat hiburan untuk menghilangkan stress.
\end{abstract}

Kata Kunci : Penyimpangan Sosial, Rumah Bernyanyi, Masyarakat.

\section{PENDAHULUAN}

Pada awalnya karaoke dikenal di negara Jepang kemudian menyebar keseluruh dunia. Karaoke merupakan salah satu alternatif hiburan yang banyak diminati oleh masyarakat. Karaoke didefinisikan sebagai sebuah bentuk hiburan dimana seseorang menyanyi diiringi dengan musik dan teks lirik. Dengan berkaraoke, seseorang dapat bernyanyi secara bebas dan leluasa sesuai kemampuan mereka. Karaoke diharapkan sebagai sebuah tempat nyaman untuk berkumpul bersama keluarga dan teman. Akan tetapi banyak orang yang menyalahgunakan tempat karaoke tersebut terutama remaja untuk pesta minuman keras, narkoba, judi bahkan sampai pada sex bebas. Seperti yang kita ketahui bahwa rumah bernyanyi yang di kota itu adalah tempat karokean yang di tempati menyanyi, untuk happy-happy dan sebagai tempat bersantai bersama keluarga dan teman, tidak ada unsur perilaku menyimpang karena memang memiliki keamanan 
yang baik contohnya saja memiliki kamera cctv di setiap ruangan bernyanyi serta selalu mendapat perhatian dari pihak yang berwajib, tapi lain dengan rumah bernyanyi yang ada di kecamatan maniangpajo kabupaten wajo dimana pelanggan sering melakukan perlakuan yang tidak senonoh dengan adat dan norma yang berlaku di tempat tersebut karena tidak memiliki keamanan yang baik serta tidak memiliki izin dari aparat yang berwenang berupa izin keramaian dari kepolisian serta tidak memiliki aturan yang jelas dalam kegiatannya.

Kehadiran rumah bernyanyi ini memiliki banyak pandangan dari masyarakat, ada yang berpendapat bahwa dengan adanya rumah bernyanyi ini akan membuat orang yang ingin mencari hiburan bersama keluarga maupun teman akan datang ke tempat karaoke hanya sekedar untuk senang-senang dan menghilangkan stres semata tanpa melakukan perbuatan yang tidak wajar tapi tidak sedikit juga yang berpendapat bahwa kehadiran rumah bernyanyi ini membawa dampak buruk bagi kalangan masyarakat khususnya remaja yang selalu ingin coba-coba karena tidak sedikit pula tempak rumah bernyanyi dijadikan tempat untuk melakukan tindakan yang melanggar norma yang ada di dalam masyarakat contohnya saja melakukan judi, minum minuman keras, bahkan dijadikan tempat mesum, tentu tindakan seperti ini sudah sangat mengganggu ketenangan dan meresahkan masyarakat sehingga pola-pola interaksi menjadi terganggu dan apabila keadaan seperti ini tidak diatasi sedini mungkin akan meyebabkan kegiatan yang ada dalam rumah bernyanyi tersebut akan semakin menjadi-jadi.

Ada berbagai faktor yang menyebabkan munculnya penyalahgunaan rumah bernyanyi yaitu diantaranya banyaknya rumah bernyanyi yang berkedok rumah bernyanyi keluarga tetapi faktanya dijadikan tempat untuk melakukan perbuatan yang menyalahi aturan yang ada, serta lemahnya pengawasan dari pihak yang berwajib sehingga pelanggan bebas melakukan apa saja apabila sudah masuk di dalam ruangan bernyanyi, tetapi selain faktor penyebab tentu ada solusi yang ditawarkan untuk menanggulangi penyalahgunaan rumah bernyanyi ini diantaranya tempat karaoke harus terbuka. Sehingga orang yang berkaraoke bisa kelihatan orang lain dan bisa meminimalisir terjadinya pelanggaran dan tindakan amoral serta meniadakan minuman keras di dalam rumah bernyanyi sehingga pelanggan tidak lagi mengomsumsi minuman keras dan tidak melakukan tindakan yang melanggar norma yang berlaku. Dari fakta tersebut diatas, dalam hal ini rumah bernyanyi perlu mendapatkan perhatian yang serius baik dari pihak yang bewenang maupun dari pemilik usaha rumah bernyanyi ini serta terfokus untuk mengarahkan remaja ke arah yang lebih positif yang titik beratnya untuk terciptanya 
ketentraman dalam masyarakat dan memanfaatkan tempat rumah bernyanyi ini sebagaimana mestinya, tidak dijadikan tempat untuk melakukan hal-hal yang tidak terpuji.

\section{LANDASAN TEORI}

Rumah bernyanyi merupakan salah satu alternatif hiburan yang banyak diminati oleh masyarakat. Karaoke didefinisikan sebagai sebuah bentuk hiburan di mana seseorang menyanyi diiringi dengan musik dan teks lirik. Orang yang melakukan karaoke bernyanyi dengan suara mereka sendiri mengikuti nada musik yang diperdengarkan. Dengan berkaraoke, seseorang dapat bernyanyi secara bebas dan leluasa sesuai kemampuan mereka. Layanan karaoke mencakup beberapa komponen penting yang terintegrasi yaitu video, text dan suara.

Video merupakan sarana visual yang dapat mengarahkan dan memudahkan seseorang saat berkaraoke. Video terintegrasi dengan teks dan suara. Teks dalam video karaoke merupakan lirik lagu yang berjalan sesuai nada lagu yang diperdengarkan. Suara dalam video karaoke merupakan suara musik instrumental dari sebuah lagu. Musik instrumental adalah suatu komposisi atau rekaman musik tanpa lirik atau musik vokal dalam bentuk apapun dan semua musik dihasilkan melalui alat musik (Wikipedia, 2008). Faktor-faktor penyebab munculnya penyalahgunaan rumah bernyanyi yaitu banyaknya tempat karaoke yang berkedok karaoke keluarga, terciptanya ruang privacy bagi para penggunanya, kurangnya sosialisasi dari orangtua ke anak mengenai nilai-nilai moral dan sosial., contoh perilaku yang ditampilkan orangtua (modeling) di rumah terhadap perilaku dan nilai-nilai anti-sosial, kurangnya pengawasan terhadap anak (baik aktivitas, pertemanan disekolah ataupun diluar sekolah, dan lainnya), kurangnya disiplin yang diterapkan orang tua pada anak, rendahnya kualitas hubungan orang tua-anak, tingginya konflik dan perilaku agresif yang terjadi dalam lingkungan keluarga, kemiskinan dan kekerasan dalam lingkungan keluarga, anak tinggal jauh dari orangtua dan tidak ada pengawasan dari figur otoritas lain, lemahnya pengawasan pihak yang berwajib.

Dalam Judistira K.Garna (1996:10-14), Persepsi merupakan proses akhir dari pengamatan yang diawali oleh proses pengindraan, yaitu proses di terimanya stimulus oleh alat indra, kemudian ada perhatian, lalu diteruskan ke otak, dan baru kemudian individu menyadari tentang sesuatu yang dinamakan persepsi. Dengan persepsi individu menyadari dapat mengerti tentang lingkungan yang ada disekitarnya maupun tentang keadaan lingkungan yang ada di sekitarnya maupun tentang hal yang ada dalam diri 
individu yang bersangkutan. Jadi, Persepsi dapat diartikan sebagai proses diterimanya rangsang melalui panca indra yang didahului oleh perhatian sehingga individu mampu mengetahui, mengartikan, dan menghayati tentang hal yang diamati, baik yang ada di luar maupun di dalam diri individu. Dalam Rakhmat (2005) Persepsi ditentukan oleh faktor personal dan faktor situasional. Menurut David Krech dan Richard S. Cruthfield dalam Rakhmat (2005:20), menyebutnya faktor fungsional dan faktor struktural. Adapun penjelasannya adalah sebagai berikut:

1. Faktor Fungsional: Faktor fungsional berasal dari kebutuhan, pengalaman masa lalu dan hal-hal lain yang termasuk dalam faktor-faktor personal. Persepsi tidak ditentukan oleh jenis atau bentuk stimuli, tetapi karakteristik orang yang memberikan respon pada stimuli tersebut.

2. Faktor Struktural: Faktor struktural berasal dari sifat stimuli fisik dan efek-efek saraf yang ditimbulkannya pada sistem saraf individu.

Selain faktor kebutuhan di atas, Leavitt (1978) juga menyatakan bahwa cara individu melihat dunia adalah berasal dari kelompoknya serta keanggotaannya dalam masyarakat. Artinya, terdapat pengaruh lingkungan terhadap cara individu melihat dunia yang dapat dikatakan sebagai tekanan-tekanan sosial. Dalam Yesmil Anwar dan Adang (2013:14) Beberapa manfaat atau keuntungan yang dapa diperoleh apabilah kita menggunakan perspektif sosologi dalam kehidupan sehai-hari, diantaranya adalah:

1. Perspektif sosiologi telah menentang (mendorong) untuk meninjau kembali pemahaman kita dan orang lain tentang pemahaman yang familiar. Dari sisni kita bisa mengkritik pemahaman yang dianggap secara umum memang begitu (eastablished) yang pada dasarnya sudah perlu dirubah.

2. Perspektif sosiologi memungkinkan kita untuk mengetahui dan memperoleh kesempatan ataunkendala dalam kehidupan kita.

3. Perspektif sosilogi memperdayakan kita untk menjadi aktif berpartisipasi dalam kehidupan bermasyaraka menuju kebaikan bersama.

4. Perspektif sosiologi menolong kita untuk mengenali perbedaan (pluralitas) manusia dan menghadap tantangan kenhidupan ldalam dunia yang bervariasi (diverse).

Dalam Bruce J. Cohen (1992 :218-219), Penyimpangan sosial atau perilaku menyimpang, sadar atau tidak sadar pernah kita alami atau kita lakukan. Penyimpangan sosial dapat terjadi dimanapun dan dilakukan oleh siapapun. Sejauh mana penyimpangan itu terjadi, besar atau kecil, dalam skala luas atau sempit tentu akan berakibat terganggunya keseimbangan kehidupan dalam masyarakat. Suatu perilaku dianggap 
menyimpang apabila tidak sesuai dengan nilai-nilai dan norma-norma sosial yang berlaku dalam masyarakat atau dengan kata lain penyimpangan(deviation) adalah segala macam pola perilaku yang tidak berhasil menyesuaikan diri (conformity) terhadap asyarakat. Para tokoh sosiologi juga menjelaskan cara pandang mereka terhadap perilaku menyimpang berdasarkan teorinya masing - masing. Adapun beberapa teori yang dapat digunakan untuk menganalisis perilaku menyimpang antara lain sebagai berikut :

1. Teori fungsi dari Emile Durkheim. Emile Durkheim berpendapat bahwa kesadaran moral dari semua masyarakat adalah karena faktor keturunan, perbedaan lingkungan fisik, dan lingkungan sosial. Jadi kejahatan akan selalu ada karena orang selalu ada yang berwatak jahat. Ia juga menjelaskan bahwa suatu kejahatan memang diperlukan bagi masyarakat, karena dengan adanya kejahatan moralitas dan hukum dapat berjalan dengan normal. Dengan dimikian peraturan akan dibuat setelah terjadi penyimpangan atau kejahatan.

2. Teori Differential Association. Teori ini disampaikan oleh Edwin H. Sutherland, ia berpendapat bahwa penyimpangan terjadi karena adanya diferensiasi atau hubungan diferensiasi. Agar seseorang bisa menyimpang, maka orang tersebut harus mempelajari terlebih dahulu bagaimana menjadi seseorang yang menyimpang. Proses penyimpangan ini bisa terjadi karena interaksi antar individu. Mereka saling berkomunikasi dan melihat kebiasaan masing - masing, kemudian mereka mnirunya. Semua proses ini bergantung pada frekuensi, prioritas, lamanya komunikasi, dan intensitas komunikasi. Jadi pada intinya penyimpangan bersumber pada pergaulan yang berbeda, dan penyimpangan dipelajari melalui proses alih budaya. Contohnya adalah proses menghisap ganja dan homoseksual.

3. Teori labelling. Teori ini disampaikan oleh Edwin M. Lemerd yang berpendapat bahwa seseorang yang telah melakukan penyimpangan pada tahap primer (pertama) lalu oleh masyarakat diberikan cap (label) sebagai penyimpang (pencuri, penjahat, $\mathrm{dsb}$ ) maka orang tersebut terdorong untuk melakukan penyimpangan sekunder (kedua dan seterusnya) dengan alasan "kepalang tanggung". Contohnya : orang yang pernah sekali mencuri karena alasan kebutuhan yang mendesak, tetapi kemudian dicap oleh masyarakat sebagai pencuri, maka ia akan terdorong menjadi pencuri, bahkan menjadi perampok.Namun dalam keadaan tertentu, pemberian cap ini justru akan mendorong kembalinya orang yang menyimpang untuk kembali berperilaku normal. Jadi, ini semua tergantung dari pelakunya. 
Dalam menilai suatu tindakan manusia sebagai penyimpangan sosial atau tidak, setiap masyarakat memiliki ukuran tersendiri. Misalnya saja meminum minuman keras, pada suatu masyarakat dapat digolongkan sebagai penyimpangan sosial, namun bagi masyarakat lainnya hal itu tidak termasuk penyimpangan sosial.

\section{METODE PENELITIAN}

Jenis penelitin yang digunakan dalam penelitian ini yaitu studi kasus dan sasaran atau tujuan penelitian dengan menggunakan pendekatan kualitatif terhadap suatu objek yang di teliti, sedangkan tipe penelitian ini bersifat deskriftif dimana peneliti akan menggambarkan suatu keadaan yang terjadi di lapangan. Informan ditentukan secara purposive sampling, tehnik pengumpulan data yaitu observasi, wawancara dan dokumentasi, kemudian dianalisis melalui analisis data dan menggunakan tehnik keabsahan data triangulasi sumber, triangulasi tehnik, dan triangulasi waktu.

\section{PEMBAHASAN}

Hiburan karaoke ini berasal dari jepang yaitu "karaoke" menurut bahasa aslinya adalah sebuah singkatan dari kaara kara dan oke, kara berarti kosong sedangkan oke berarti orkestra. Karaoke berarti sebuah musik orkestra yang kosong atau tidak dilengkapi dengan suara vokal. Rumah bernyanyi merupakan salah satu alternatif hiburan yang banyak diminati oleh masyarakat.

Karaoke didefinisikan sebagai sebuah bentuk hiburan di mana seseorang menyanyi diiringi dengan musik dan teks lirik. Orang yang melakukan karaoke bernyanyi dengan suara mereka sendiri mengikuti nada musik yang diperdengarkan. Dengan berkaraoke, seseorang dapat bernyanyi secara bebas dan leluasa sesuai kemampuan mereka. Layanan karaoke mencakup beberapa komponen penting yang terintegrasi yaitu video, text dan suara. Video merupakan sarana visual yang dapat mengarahkan dan memudahkan seseorang saat berkaraoke. Video terintegrasi dengan teks dan suara. Teks dalam video karaoke merupakan lirik lagu yang berjalan sesuai nada lagu yang diperdengarkan. Suara dalam video karaoke merupakan suara musik instrumental dari sebuah lagu. Musik instrumental adalah suatu komposisi atau rekaman musik tanpa lirik atau musik vokal dalam bentuk apapun dan semua musik dihasilkan melalui alat musik (Wikipedia, 2008). Dengan musik instrumental, pengguna karaoke dapat bernyanyi seolah-seolah mereka adalah penyanyi yang sebenarnya tanpa terganggu oleh suara penyanyi aslinya. layanan Karaoke online mencakup tiga bidang layanan. Pertama, 
Layanan Karaoke yang merupakan layanan utama dalam aplikasi ini. Layanan karaoke ini bertujuan memberikan fasilitas karaoke bagi anggota web yang sudah terdaftar. Anggota web dapat memilih video lagu yang tersedia kemudian melakukan karaoke dengan melihat video lagu tersebut.

Persepsi positif yang timbul dari keberadaan rumah bernyanyi informan menganggap bahwa tempat hiburan tersebut mempunyai manfaat bagi sebagian masyarakat. Informan juga merasa bahwa tempat hiburan malam tersebut selama tidak mengganggu masyarakat yang berada di daerah tersebut tidak menjadi suatu permasalahan, karena menurut informan tempat hiburan malam sebagai salah satu sarana melepas stres dan bahkan dapat juga dikatakan hanya sebagian masyarakat yang berkunjung ke sana dan itu juga hanya orang-orang tertentu. Sedangkan persepsi negatif yang berkembang ditengah masyarakat akibat dari keberadaan rumah bernyanyi Informan yang memiliki persepsi negaitif terhadap rumah, informan berpendapat tempat hiburan tidak sesuai dengan norma dan nilai-nilai masyarakat di kecamatan maniangpajo yang telah di tanam dengan baik pada masyarakat, hal ini apabila tidak ditanggapi dengan serius maka akan menimbulkan kemunduran atau pudarnya nilai-nilai yang ada di tengah masyarakat.

\section{KESIMPULAN}

Berdasarkan hasil analisis data dan pembahasan yang telah diuraikan pada bab IV, maka peneliti dapat mengambil kesimpulan sebagai berikut:

1. Persepsi masyarakat tentang rumah bernyanyi di kecamatan maniangpajo ini, ada sebagian masyarakat menganggap bahwa rumah bernyanyi ini membawa suatu manfaat selama tidak mengganggu kenyamanan masyarakat sekitar.

2. Namun persepsi sebagian besar masyarakat menganggap kehadiran rumah bernyanyi ini membawa dampak buruk terutama dari kalangan remaja.

3. Rumah bernyanayi membawa dampak negatif bagi warga masyarakat di sekitaran rumah bernyanyi itu sendiri yaitu keributan yang dilakukan oleh pengunjung di luar rumah bernyanyi ini selain itu banyaknya anak sekolah yang lebih memilih ke main karaoke dari pada masuk sekolah membuat banyak orang tua anak-anak ini mengeluh.

4. Rumah bernyanyi ini juga membawa dampak positif bagi sebagian kecil warga masyarakat di daerah rumah bernyanyi ini terutama bagi pekerja atau pegawainya yang membuat kondisi ekonomi mereka lebih baik sama halnya dengan tukang parkir 
di rumah bernyanyi ini yang mendapatkan keuntungan lebih sejak adanya rumah bernyanyi tersebut.

5. Pelabelan terhadap remaja menyebabkan remaja melakukan penyimpangan seperti mabuk-mabukan, bolos dari sekolah dan lain-lain.

\section{DAFTAR PUSTAKA}

Cohen Bruce J. (1992). Sosiologi suatu pengantar. Jakarta : rineka cipta

Ermalinda, Paizaluddun. (2013). Penelitian tindakan kelas panduan teoritis dan praktis. Bandung : alfabeta.

Goodman Douglas J. George Ritzer. (2014). Teori-teori sosiologi.jakarta kreasi: wacana

Judistira K. Garna. (1996). Ilmu-ilmu sosialdasar konsep posisi. Bandung : program pasca sarjana universitas padjadjaran.

Lincoln dan Guba. (1981).metode penelitian kuantitatif dan kualitatif. Bandung : alfabeta

Moleong Lexy J. (2007). Metode penelitian kualitatif. Bandung : Rosdakarya

Soekanto, Soerjono. (2012). Sosiologi suatu pengantar. Jakarta : PT. raja grafindo persada

Sugiyono. (2012). Metode penelitian kombinasi (mixed metods). Bandung : Alfabeta

Suyanto Bagong. (2013). Masalah sosial anak. Surabaya kecana

Tim Penysun FKIP Unismuh Makassar. (2012). pedoman penulisan skripsi. Makassar :panrita press unismuh makassar.

Waters. (1994). Teori sosiologi modern. Surabaya : yayasan kesatuan umat

Ignas Kleden. (2006). Pierre bourdieu dan konsep habitus baru (online) (http//habitus baru.blogspot.com) (diakses 20 mei 2015)

Izzah Rumaha. (2012). Faktor penyebab dan dampak penyimpanan sosial (online)(http//izzah rumaha.blogspot.com (diakses 20 mei 2015)

Reza A.A Wattimena. (2012) filsuf dan sosiolog asal perancis (online) (http//rumahfilsafat.com) (diakses 20 mei 2015)

Riyanto, Arudam. (2015). Pengertian rumah bernyanyi (online) (http//kanalku.blogspot.com)

Wikipedia. (2008). Musik instrumental (online) (http//id.m.wikipedia.org/wiki) (diakses 20 mei 2015) 
Yudha, Irfan,. (2013). Dampak pembangunan rumah bernyanyi (online) (http// scripd.com) (diakses 20 mei 2015) 